\title{
PERSEPSI AKADEMISI MUSLIM DI KOTA METRO TERHADAP AJARAN MENDIRIKAN NEGARA ISLAM
}

\author{
Dri Santoso, Muhamad Nasrudin
}

Institut Agama Islam Negeri Metro, Lampung | Jl. Ki Hajar Dewantara No. I 5A, Iringmulyo, Kota Metro, Lampung

drisantoso@metrouniv.ac.id

\begin{abstract}
: this article studies the perception of muslim academia in the City of Metro on the idea of establishing Islamic state in Indonesia. This study involves academia fro four universities in Metro two of which are affiliated to Islamic organization of Nahdlatul Ulama and Muhammadiyah, whereas the rest two are not affiliated to any Islamic organization. Academia in this study hold important positions in campus as well as in community, interviews are conducted for the study. The study shows that the majority of academia believe that establishing Islamic state in Indonesia is not a religious obligation because islam does not clearly oblige it they believe that the current establishment of Indonesian nation-state as final and ideal for Indonesian context. However, they are sharply divided concerning implementing sharia. While some refuse it on the ground of religious plurality in Indonesia, others firmly support sharia as part of local aspiration.
\end{abstract}

Key words: muslim academia, Islamic state, Indonesia

Abstrak: Artikel ini mengkaji bagaimana persepsi akademisi muslim di Kota Metro terhadap ajaran kewajiban mendirikan negara Islam di Indonesia. Kajian ini melibatkan akademisi dari empat Perguruan Tinggi (PT) di Kota Metro. Empat PT ini diambil dengan preferensi dan afiliasi ormas, yakni: Nahdlatul Ulama, Muhammadiyah, dan dua PT yang netral. Akademisi yang dipilih adalah mereka yang memiliki posisi struktural cukup penting di kampus dan posisi yang juga penting dalam struktur sosial di lingkungan masing-masing. Metode yang digunakan adalah wawancara mendalam. Hasilnya, persepsi akademisi terhadap negara-bangsa Indonesia adalah positif. Sebaliknya persepsi cenderung negatif atau menolak ajaran kewajiban mendirikan negara Islam. Bagi mereka, negara-bangsa Indonesia adalah bentuk final dan ideal. Selain itu, Islam dinilai tidak mengatur rigid bagaimana seharusnya umat Islam bernegara. Penerapan syariat Islam dalam ranah publik juga ditolak.

AL-DAULAH: JURNAL HUKUM DAN PERUNDANGAN ISLAM VOLUME 8, NOMOR 1, APRIL 2018

p-ISSN 2089-0109; e-ISSN 2503-0922

Homepage: http://jurnalfsh.uinsby.ac.id/index.php/aldaulah

Email: judulsj@gmail.com 
Sedangkan terhadap perda syariat, akademisi muslim Kota Metro mendua, sebagian menolak dengan alasan keadilan warganegara nonmuslim, dan sebagian menerima perda syariat sebagai wujud aspirasi masyarakat lokal.

Kata Kunci: Akademisi muslim, negara Islam, NKRI.

\section{Pendahuluan}

Bangsa Indonesia sudah sepakat mendirikan Negara Kesatuan Republik Indonesia yang berbentuk negara kesatuan, berlandaskan Pancasila dan Undang-Undang Dasar 1945, bukan negara Islam maupun kekhilafahan. Bentuk yang demikian dianggap sebagai bentuk yang paling ideal untuk mempersatukan segenap anak bangsa yang terdiri dari berbagai macam suku, ras, agama, serta golongan. Konsensus pembentukan negara yang berlandaskan Pancasila dan UUD 1945 tersebut diperoleh melalui proses panjang sejak pra kemerdekaan hingga masa kini.

Meskipun mayoritas anggota Panitia Persiapan Kemerdekaan Indonesia (PPKI) beragama Islam, kepentingan bangsa dan negara jauh lebih diutamakan ketimbang kepentingan golongan tertentu. Kendatipun umat Islam sebagai warga negara mayoritas awalnya berpendirian bahwa klausul "kewajiban menjalankan syariat Islam bagi pemeluk-pemeluknya" dicantumkan pada dasar negara. Akan tetapi pada akhirnya mereka rela untuk membatalkan tuntutan tersebut dan menyetujui teks sila pertama sehingga berbunyi "Ketuhanan Yang Maha Esa". ${ }^{1}$

Bahkan salah satu tokoh yang merelakan penghapusan klausul tersebut adalah Abdul Wahid Hasyim, putra pendiri Nahdlatul Ulama. ${ }^{2}$ Ia adalah salah satu anggota tim sembilan Panitia Persiapan Kemerdekaan Indonesia (PPKI). Ia lebih mengutamakan persatuan dan kesatuan bangsa daripada kepentingan kelompok primordial dimana ia semula berasal.

I Imam Amrusi Jailani, "Tarik Ulur Islam dan Dasar Negara," al-Daulah: Jurnal Hukum dan Perundangan Islam 2, No. I, I April 20 I2, I-2I.

2 Rijal Mumazziq Zionis, "Relasi Agama dan Negara Perspektif KH. A. Wahid Hasyim dan Relevansinya dengan Kondisi Sekarang," al-Daulah: Jurnal Hukum dan Perundangan Islam 5, No. 2, I Oktober 20I5, 333-359. 
Setelah puluhan tahun Indonesia merdeka, kerinduan dan tuntutan untuk mewujudkan negara Islam dalam wujud tegaknya kekhalifahan untuk menjamin terlaksananya syariah nyaring terdengar kembali. Era reformasi yang identik dengan kebebasan berpendapat, demokrasi, pengakuan terhadap hak-hak warga negara dijadikan momentum untuk menyerukan kembali pentingnya pendirian negara Islam.

Di antara kelompok yang terang-terangan menyerukan hal tersebut adalah Hizbut Tahrir Indonesia (HTI), Majelis Mujahidin Indonesia (MMI), dan Jamaah Islamiah (JI), Darul Islam/Negara Islam Indonesia/Tentara Islam Indonesia (DI/NII/TII). Hizbut Tahrir Indonesia (HTI) berpandangan bahwa kemiskinan dan kebodohan serta menjamurnya kemaksiatan di Indonesia disebabkan oleh hukum yang diberlakukan di Indonesia bukan hukum Islam. Oleh karena itu, untuk menumpas kemaksiatan harus diberlakukan syariat Islam dan untuk menegakkan syariat Islam, maka harus diberlakukan sistem kekhalifahan. ${ }^{3}$

Para pengusung ide negara Islam ini berpandangan bahwa wacana pembentukan kekhalifahan melalui perjuangan secara damai dijamin oleh Pasal 28 ayat (1) UUD 1945 tentang kebebasan berkumpul dan mengeluarkan pendapat, sehingga tidak dapat dipidanakan sepanjang tidak bersifat anarkis. Walaupun demikian, pada dasarnya hal tersebut bertentangan dengan citacita berdirinya negara Indonesia yang tercantum dalam pembukaan Undang-Undang Dasar 1945 dan Pancasila yang sudah menjadi konsensus para pendiri bangsa untuk membuat negara kesatuan yang mengakomodir kepentingan semua golongan.

Perjuangan pendirian negara Islam selama ini ditempuh dengan cara damai yaitu dengan menggelar demonstrasi, diskusi, lokakarya, dan ceramah-ceramah di masjid, yang bertujuan untuk menggaet simpati dan dukungan dari umat Islam. Forum-forum

3 Muhammadin, "Gerakan Dakwah Hizbut Tahrir Indonesia," Jurnal IImu Agama 17, No. I, I 3 Juli 2016, 47-62. 
tadi dipenuhi dengan wacana mengenai pentingnya pendirian kekhalifahan sebagai satu-satunya cara untuk mengentaskan umat dari jurang keterbelakangan dan menjadikannya sebagai umat yang maju dan mampu berkompetisi dengan dunia lain sebagaimana pernah dicapai oleh kehalifahan Islam masa lalu. Wacana ini selalu mengambil tamsil kejayaan masa Khulafa' Rasyidun, Dinasti Umayyah, Dinasti Abasiyah, dan Turki Utsmani. ${ }^{4}$

Kelompok ini di Indonesia lazimnya mengambil inspirasi dari tokoh-tokoh revivalis tekstualis transnasional seperti Rasyid Ridha, al-Maududi, Hasan al-Banna dan Taqiy al-Din al-Nabhani. Hasan al-Banna dikenal sebagai tokoh penting di organisasi Ikhwan al-Muslimin yang sangat mendukung pendirian kembali khilafah Islamiyah. Sementara itu, Taqiy al-Din adalah tokoh pendiri Hizbut Tahrir, partai politik lintas negara yang juga bertujuan mendirikan kekhilafahan Islam. ${ }^{5}$

Pada sisi lain, mayoritas umat Islam di Indonesia berhaluan moderat. Mereka menerima Negara Kesatuan Republik Indonesia yang berdasarkan pada Pancasila dan Undang-Undang Dasar 1945. Mayoritas umat Islam mengakui keberagaman etnis, ras, dan agama. Melalui organisasi kemasyarakatan Islam terbesar yaitu Nahdlatul Ulama (NU) dan Muhammadiyah, mereka menyetujui dan menilai Negara Kesatuan Republik Indonesia adalah negara kebangsaan yang damai (Darussalam) sebagai bentuk final, bukan negara agama atau kekhalifahan atau Darul Islam. ${ }^{6}$

Kelompok ini sangat dominan di Indonesia. Abdurrahman Wahid, misalnya, salah satu cucu pendiri Nahdlatul Ulama, dan pernah menjadi Ketua Umum Pengurus Besar Nahdlatul Ulama

\footnotetext{
${ }^{4}$ Mohamad Rafiuddin, "Mengenal Hizbut Tahrir (Studi Analisis Ideologi Hizbut Tahrir vis a vis NU)," ISLAMUNA: Jurnal Studi Islam 2, No. I, 5 Juni 2015, 29-55, https://doi.org/10.19105/islamuna.v2il.653.

${ }^{5}$ Achmad Yasin, "Pemetaan Pemikiran Islamic State, Khilafah dan Nation State Perspektif Figh alSiyasi," al-Daulah: Jurnal Hukum dan Perundangan Islam 2, No. 2, I Oktober 20 I2, I6 I-84.

${ }_{6}$ Miftahul IImi, Persepsi Ulama NU tentang Sistem Khilafah, (Semarang: Skripsi Fakultas Syari'ah IAIN Walisongo, 2008), 3.
} 
menyatakan bahwa demokrasi adalah sistem yang paling masuk akal untuk diterapkan negeri ini. Meskipun Islam tidak menjadi dasar bernegara, Islam menyediakan landasan dalam bernegara, yakni prinsip kebebasan, keadilan, kesetaraan, kebebasan, dan persaudaraan. Dengan kata lain, demokrasi adalah sistemnya, sedang Islam menyediakan fondasi dan ruhnya. ${ }^{7}$

Meskipun demikian, terdapat beberapa kelompok umat Islam yang masih memimpikan berdirinya negara Islam, baik secara sembunyi-sembunyi maupun terang-terangan. Di antara mereka ada yang memperjuangkannya secara damai seperti yang dilakukan oleh Hizbut Tahrir Indonesia. Gerakan HTI di Indonesia pada tahun 2017 dinyatakan sebagai ormas terlarang dan dibubarkan oleh pemerintah.

Di antara kelompok Islamis, atau Islam politik, ada juga yang memperjuangkan cita-citanya terkait negara Islam dengan cara radikal. Dalam konteks kontemporer, gerakan ini biasanya dilakukan oleh kelompok teroris, baik yang berafiliasai dengan alQaidah maupun yang berafilisai dengan ISIS. Adapun dalam konteks lokal Indonesia, ada juga yang pernah melakukan pemberontakan, yakni DI/TII yang sempat memproklamirkan berdirinya negaranya.

Selain itu, ada juga yang melakukannya secara sembunyisembunyi sembari ikut dalam pemilihan umum. Secara formal, AD/ART partai politik ini berdasarkan Islam dan sebagai wadah bagi umat Islam untuk menyuarakan aspirasinya. Salah satu aspirasi yang sedang dikejar saat ini adalah penerapan syariat Islam dalam ranah publik, baik dilakukan melalui mekanisme qânûn atau peraturan daerah. Secara jangka panjang, mereka ingin agar seluruh ajaran Islam bisa diterapkan dalam keseharian secara kâffah.

Sementara itu, di kalangan masyarakat, terdapat akademisi muslim sebagai individu yang terdidik pada strata tertinggi di

7 Saoki, "Islam dan Negara Menurut M. Natsir dan Abdurrahman Wahid," al-Daulah: Jurnal Hukum dan Perundangan Islam 4, No. 02, Tahun 2014, 344-367. 
dunia pendidikan Indonesia. Kelompok ini tidak hanya beraktivitas sebagai pendidik, peneliti, dan pengabdi yang senantiasa mencurahkan kapasitas intlektualnya di kampus. Mereka juga memiliki pengaruh tidak saja pada mahasiswanya di kampus, tetapi juga di masyarakat sebagai tokoh atau elit sosial. Sebagai elit sosial mereka memegang peranan penting dan memiliki pengaruh dalam masyarakat. Pemikiran, sikap hidup, dan tindak tanduknya senantiasa menjadi panduan atau referensi bagi masyarakat. ${ }^{8}$

Oleh karena akademisi muslim memiliki peran yang strategis bagi masyarakat, maka mereka harus terus-menerus mempelajari kandungan al-Qur'an dan sumber-sumber kajian tradisi keilmuan Islam agar memiliki pemahaman yang utuh, termasuk dalam hal tata kenegaraan dalam Islam. Hal lain yang harus dikuasai oleh akademisi adalah kemampuan memahami realitas sosial sehingga dapat mengambil bagian, terlibat, dan mengatasi persoalan masyarakat. Yang terakhir ini telah ditunaikan oleh para akademisi muslim pada zaman perjuangan kemerdekaan Indonesia. Mereka memberikan sumbangan yang besar pada perumusan dasar dan konstitusi Negara Kesatuan Republik Indonesia. ${ }^{9}$

Peran akademisi muslim bagi masyarakat dapat dilakukan melalui berbagai cara, mulai dari persepsi, keyakinan, sikap, hingga perilakunya. Persepsi akademisi muslim terhadap suatu hal senantiasa menjadi role model bagi civitas akademika maupun masyarakat sekitar untuk mengambil sikap dan bertindak di dalam maupun di luar kampus. Muhammad Hatta berpendapat bahwa seorang akademisi memiliki tanggung jawab moral dari setiap pikiran dan tindakannya. ${ }^{10}$ Oleh karena itu, menarik dan

\footnotetext{
${ }^{8}$ Abu Ahmadi, IImu Sosial Dasar, (Jakarta: Rineka Cipta, 1997), 57.

9 M. Quraish Shihab, "Membumikan" Al-Quran: Fungsi dan Peran Wahyu dalam Kehidupan Masyarakat, (Bandung: Mizan Pustaka, 2007), 390.

10 Muhammad Hatta, "Tanggungjawab Moral Kaum Intelegensia," Cendikiawan dan Politik (Jakarta: LP3ES, 1984).
} 
penting mengetahui persepsi akademisi muslim di Kota Metro Lampung terhadap pendirian negara Islam di Indonesia.

Tulisan ini mengkaji perwakilan akademisi di empat Perguruan Tinggi di Kota Metro. Keempat Pergguruan Tinggi adalah Universitas Muhammadiyah Metro yang merepresentasikan ormas Muhammadiyah. Selanjutnya Institut Agama Islam Maarif (IAIM) NU Metro yang merepresentasikan ormas Nahdlatul Ulama. Kemudian Institut Agama Islam Negeri (IAIN) Metro dan Institut Agama Islam (IAI) Agus Salim yang netral, tidak berafiliasi dengan ormas keagamaan tertentu.

\section{Hukum Mendirikan Negara}

Ulama bersepakat dalam hal urgensi mendirikan negara. Kehadiran negara diperlukan sebagai mekanisme kerjasama antar manusia untuk mencapai tujuan hidupnya. Berkaitan dengan hal tersebut, Ibnu Taimiyah berpendapat: Umat Islam tidak mungkin memenuhi segala kebutuhan hidupnya tanpa kerjasama dan saling membantu dengan orang lain. Karena itulah manusia hidup berkelompok dan setiap kelompok memerlukan seorang pemimpin. Oleh karena itu, mendirikan negara untuk mengelola urusan umat merupakan kewajiban agama yang paling agung, karena agama tak mungkin tegak tanpa pemerintahan. Allah memerintahkan amar makruf dan nahi munkar. Tugas tersebut tidak mungkin terlaksana tanpa kekuatan kekuasaan dan pemerintahan. ${ }^{11}$

Pada sisi yang sama dengan Ibnu Taimiyah, ada Imam Ghazali yang berpendapat bahwa keberadaan kepala negara diperlukan tidak hanya untuk menjamin keselamatan jiwa dan hak milik rakyat, terpenuhinya kebutuhan materi mereka saja. Lebih dari hal itu, keberadaan kepemimpinan adalah untuk menjamin berlakunya segala perintah dan hukum Allah. ${ }^{12}$ Ibnu Khaldun

I Munawir Sjadzali, Islam dan Tata Negara; Ajaran, Sejarah dan Pemikiran, Jakarta: UI Press, 1993), 89.

$12 \mathrm{lbid}$. 
berpendapat bahwa adanya organisasi kemasyarakatan merupakan keharusan bagi hidup manusia, sebagaimana telah dikemukanan oleh ahli filsafat. Manusia merupakan makhluk sosial. Manusia tidak akan hidup tanpa organisasi kemasyarakatan yang oleh ahli filsafat disebut kota, contohnya untuk mendapatkan makanan. Kita memerlukan petani yang menanam, agar sekarung gandum/beras yang diproduksi petani sampai di atas meja hidangan diperlukan banyak profesi yang saling mendukung dan bekerja sama. Begitu juga dalam mencukupi kebutuhan hidup lainnya, manusia memerlukan banyak orang yang saling bahumembahu dalam menjalani dan mempertahankan kehidupan. Organisasi masyarakat yang terdiri dari ragam bentuk peran atau profesi dalam masyarakat memerlukan seorang pemimpin. Kombinasi antara kumpulan orang lazim disebut warga negara dengan pemimpinnya dan mendiami sebuah wilayah, maka lahirlah sebuah negara. ${ }^{13}$

Terbentuknya negara merupakan sesuatu yang niscaya (sunnatullah), sebagai akibat dari kodrat manusia sebagai makhluk sosial yang memerlukan bantuan manusia lainnya. Dari sini kemudian manusia bersatu secara terorganisir, ada yang memimpin dan ada yang dipimpin dalam sebuah wilayah/kota untuk mencapai tujuan sacara bersama. Hal ini merupakan cikalbakal terbentuknya negara. Pendapat demikian disampaikan oleh beberapa filosof Islam, di antaranya Ibu Arabi, al-Farabi dan alMawardi.

Al-Mawardi menyatakan ada banyak hewan yang mampu hidup sendirian dan tidak membutuhkan hewan lainnya. Namun Allah menciptakan manusia sebagai makhluk yang paling membutuhkan terhadap sesamanya. Memerlukan bantuan sesama adalah sifat yang inheren pada diri manusia. Hal demikian didasarkan pada firman Allah: "Manusia diciptakan dalam keadaan lemah". Manusia adalah makhluk yang paling besar 
kebutuhannya dibandingkan dengan makhluk lain, maka ia adalah makhluk yang paling lemah. Sebab butuh sesuatu berarti dia tidak memilikinya. Makhluk yang membutuhkan sesuatu berarti lemah. ${ }^{14}$ Kesadaran manusia bahwa mereka tidak mampu hidup sendiri mendorong manusia untuk berorganisasi. Organisasi masyarakat yang teratur dengan memenuhi syaratsyarat tertentu inilah yang disebut negara.

Menurut Al-Mawardi negara yang ideal memerlukan enam sendi utama, yaitu:

a. Agama yang dihayati; agama diperlukan untuk mengontrol dan mengawasi kemungkinan terjadinya penyimpangan kekuasaan.

b. Pemimpin yang berwibawa; dengan kewibawaannya, ia akan dipatuhi oleh rakyatnya, sehingga sanggup mempersatukan perbedaan dari berbagai aspek, dan dapat memimpin dalam rangka memelihara agama, memelihara dan mensejahterakan rakyat, memelihara keamanan dan ketertiban.

c. Keadilan yang menyeluruh; kepala negara hendaknya dapat mewujudkan cita-cita keadilan bagi seluruh rakyatnya, keadilan dimulai dari diri sendiri lalu keadilan terhadap orang lain yang meliputi:

1) Keadilan terhadap bawahan

2) Keadilan terhadap atasan

3) Keadilan terhadap masyarakat yang setingkat.

d. Menciptakan keamanan dan ketertiban, yang dapat dirasakan oleh seluruh rakyatnya.

e. Menciptakan kemakmuran; dengan tersedianya kebutuhan hidup primer seperti sandang, pangan, dan papan. Terciptanya kehidupan yang berkelanjutan; terwujudnya anak-anak calon generasi penerus yang sehat lahir batin, adanya harapan hidup yang lebih baik pada masa mendatang. ${ }^{15}$

\footnotetext{
${ }^{14}$ Ali Abdul Mu'ti Muhammad, Filsafat Politik Antara Islam dan Barat, terj. oleh Rosihan Anwar, (Bandung: Pustaka Setia, 20 I0), 367.

15 Ibid., 368-369.
} 


\section{Bentuk Negara dalam Islam}

Bentuk negara yang maksud dalam tulisan ini adalah apakah negara yang dibentuk oleh umat Islam wajib berbentuk khilafah atau negara Islam, atau tergantung kehendak umat Islam di wilayahnya masing-masing. Artinya, umat Islam boleh mendirikan negara dalam bentuk negara bangsa/nation-state. Sampai saat ini, polemik terkait bentuk negara dalam Islam belum juga mendapatkan titik temu. ${ }^{16}$

Perbedaan pendapat tersebut disebabkan oleh tidak adanya nash al-Qur'an yang secara tegas memerintahkan umat Islam untuk mendirikan negara dan menentukan bentuk negara. Dalam catatan sejarah, Nabi tidak pernah mendeklarasikan formulasi baku tentang bentuk negara dan tidak pernah memformalkan pemerintahannya di Madinah sebagai bentuk negara yang ideal. Ketika meninggal, Nabi tidak meninggalkan wasiat dan menunjuk siapa yang berhak menggantikan beliau sebagai pemimpin umat. Pemilihan pengganti beliau yang dikenal sebagai Khulafaurrasyidin semata-mata atas dasar ijtihad para Sahabat, karenanya pemilihan keempat khalifah, yakni: Abu Bakar Siddiq, Umar bin Khattab, Usman bin Affan dan Ali bin Abi Thalib dilakukan dengan sistem dan cara yang berbeda-beda. ${ }^{17}$

Kondisi di atas memberi ruang kepada ulama untuk berijtihad mengistinbatkan pendapatnya masing-masing: bentuk negara seperti apa yang harus didirikan, apakah menggunakan sistem khilafah atau negara-bangsa, sebagaimana sekarang banyak dilakukan oleh negara-negara Islam di dunia termasuk di Indonesia. Dalam hal ini Munawir Sadzali berpendapat bahwa di kalangan umat Islam sampai saat ini terdapat tiga kelompok pendapat tentang hubungan antara Islam dan ketatanegaraan. ${ }^{18}$

\footnotetext{
16 Yasin, "Pemetaan Pemikiran Islamic State, Khilafah dan Nation State Perspektif Fiqh al-Siyasi."

17 Ma'shum, "Islam dan Pencarian Identitas Politik (Ambiguitas Sistem Khilafah dalam Institusi Politik Islam)," Asy-Syir'ah: Jurnal IImu Syari'ah dan Hukum, 47, no. 2 (I Juli 2013), http://asysyirah.uin-suka.com/index.php/AS/article/view/7I.

18 Yasin, "Pemetaan Pemikiran Islamic State, Khilafah dan Nation State Perspektif Fiqh al-Siyasi."
} 
a. Kelompok pertama menyatakan bahwa Islam bukanlah sematamata agama dalam pengertian Barat, yakni hanya menyangkut hubungan antara manusia dan tuhan. Sebaliknya, Islam adalah satu agama yang sempurna dan lengkap. Ajarannya memuat segala aspek kehidupan manusia termasuk kehidupan bernegara. Para penganut aliran ini pada umumnya berpendirian bahwa:

1) Islam adalah agama yang serba lengkap, di dalamnya terdapat pula antara lain sistem ketatanegaraan atau politik. Oleh karena itu, dalam bernegara umat Islam hendaknya kembali ke sistem kenegaraan Islam, tidak perlu bahkan meniru sistem ketatanegaraan Barat.

2) Sistem ketatanegaraan atau politik islami yang harus diteladani adalah sistem politik yang telah dilaksanakan oleh Nabi dan Khulafaurrasyidun. Pendapat demikian didukung oleh: Ibnu Taimiyah, Syekh Hasan al-Banna, Sayyed Quthb, Muhammad Rasyid Ridha, dan Abul A'la Al-Maudhudi. ${ }^{19}$

b. Kelompok kedua menyatakan bahwa Islam merupakan agama dalam pengertian Barat, yakni tidak ada hubungan antara agama dengan urusan ketatanegaraan. Menurut pendapat ini Nabi Muhammad hanyalah seorang Rasul biasa sebagaimana rasul-rasul sebelumnya dengan tugas tunggal mengajak umat manusia kembali kepada kehidupan yang mulia dengan menjujung tinggi budi pekerti luhur (akhlak karimah). Keberadaan Nabi Muhammad di muka bumi tidak pernah ditujukan untuk mendirikan dan mengepalai suatu negara. Tokoh tokoh terkemuka kelompok ini adalah: Ali Abd al-Razik dan Thaha Husen. ${ }^{20}$

c. Kelompok ketiga menolak pendapat bahwa Islam adalah agama yang serba lengkap dan bahwa ajaran Islam memuat soal sistem kenegaraan. Pendapat ini juga menolak pandangan

19 Munawir Sjadzali, Islam dan Tata Negara; Ajaran, Sejarah dan Pemikiran, 99.

20 lbid., 99- 100. 
bahwa Islam adalah agama dalam pengertian Barat yang hanya mengatur hubungan antara manusia dan penciptanya. Mereka berpendirian bahwa dalam Islam tidak terdapat sistem ketatanegaraan tetapi terdapat seperangkat tata nilai etika bagi kehidupan bernegara. Di antara tokoh-tokoh penganjur pendapat ini yang menonjol adalah: Dr. Muhammad Husein Haikal.

a) Implikasi kelompok pertama yang berkeyakinan bahwa Islam adalah agama paripurna yang mengatur semua aspek kenegaraan, maka menurut mereka umat Islam wajib melaksanakan sistem kenegaraannya sendiri, menolak sistem Barat yang selama ini digunakan. Oleh karena itu, membentuk negara Islam wajib hukumnya. Indikasi negara Islam adalah menjadikan hukum Islam dalam kehidupan berbangsa dan bernegara. Mereka menolak sistem demokrasi dan menganjurkan kembali ke sistem Islam yaitu syûr. Berikut pendapat Sayyid Qutb mengenai garis-garis besar negara Islam yang diperjuangkannya dalam wadah organisasi Ikhwanul Muslimin..$^{21}$ Pemerintahan supranasional; pemerintahan yang dibentuk adalah pemerintahan satu kesatuan umat Islam, tidak mengenal batas bangsa dan nasionalisme. Hanya ada satu negara Islam di dunia, pemerintah pusat dipimpin oleh seorang khilafah.

b) Kepemimpinan negara atau imamah berfungsi sebagai pengganti kenabian, tetapi tidak berarti kepala negara atau imam memiliki kekuasaan keagamaan yang diterimanya dari Allah. Dia menjadi kepala negara semata-mata karena dipilih oleh kaum muslimin dan merekalah yang mengawasinya dan berhak menurunkanya dari jabatan kepala negara kalau menyeleweng dan tidak melaksanakan syariat Islam.

21 Yasin, "Pemetaan Pemikiran Islamic State, Khilafah dan Nation State Perspektif Figh al-Siyasi." 
c) Negara Islam menjamin kebebasan dan persamaan derajat bagi golongan non-Islam, tetapi hak menjadi kepala negara dan hak memilih kepala negara hanya eksklusif menjadi milik warga negara yang beragama Islam.

d) Pemerintahan Islam adalah pemerintahan yang menerima Islam sebagai agamanya dan melaksanakan syariat Islam, tentang bentuk negara apakah monarkhi atau republik, dapat diterima sepanjang dapat menjalankan syariat Islam, dan berdasarkan asas keadilan, persamaan, ketaatan rakyat dan permusyawaratan antara penguasa dan rakyat dalam hal-hal yang belum ditentukan penyelesaiannya dalam nash al-Quran atau hadis. ${ }^{22}$

Abu al-A'la al-Maududi menyatakan bahwa Islam adalah agama yang sempurna dan mencakup segala aspek kehidupan, maka tidaklah perlu umat Islam mengambil ajaran di luar Islam sebagai pedoman bernegara. ${ }^{23}$ Sebagai salah seorang tokoh kelompok pertama, al-Maududi berpendapat bahwa bentuk negara Islam adalah sebagai berikut:

1. Sistem politik Islam universal dan tidak mengenal batas-batas dan ikatan geografis, bahasa, dan kebangsaan.

2. Sistem kenegaraan Islam bukanlah sistem demokrasi yang dianut Barat yang menyatakan sumber kekuasaan dari rakyat, karena sistem kekuasaan kenegaraan dalam Islam bersumber dari Allah swt, manusia sebagai pelaksana atau khalifahnya.

3. Badan eksekutif dibentuk oleh umat Islam begitu juga dalam hal pengawasan, umat Islam juga berhak memecat penguasa yang menyimpang dan melanggar hukum-hukum Allah.

4. Kekuasaan negara dilakukan oleh tiga lembaga badan eksekutif atau pemerintah yang bertanggung jawab kepada Allah swt dan kepada rakyat, eksekutif dalam menjalankan tugasnya

22 Munawir Sjadzali, Islam dan Tata Negara; Ajaran, Sejarah dan Pemikiran, 100.

23 Abu Dzarrin al-Hamidy, "Landscape Pemikiran Abu al-A'la al-Mawdudi ( 1903-1979) tentang Konsep Negara Islam," al-Daulah: Jurnal Hukum dan Perundangan Islam I, No. 2 (I Oktober 201 I), 207-39. 
harus berkonsultasi dengan Majelis Syura (legislatif) dan badan yudikatif. ${ }^{24}$

Di antara kelompok pertama ini adalah Hizbut Tahrir. Hizbut Tahrir merupakan sebuah partai yang didirikan di kota Al-Quds Palestina oleh Taqiyudin al-Nabhani pada tahun 1953. Hizbut Tahrir mencita-citakan adaanya Daulah Islamiyyah atau yang populer disebut sebagai khilafah. Khilafah sebagai implementasi ajaran Islam yang kâffah dan sebagai jalan keluar dari segala keterpurukan yang selama ini dirasakan oleh umat Islam. Konsep khilafah merupakan sistem negara yang bersifat supra-nasional, melampaui batasan geografis, bahasa, dan kebangsaan. ${ }^{25}$

Kelompok ketiga menyatakan bahwa Islam tidak memuat ajaran ketatanegaraan dalam arti tidak ada ayat al-Qur'an atau Hadis Nabi yang menunjuk langsung secara qath'i tentang bentuk negara dan sistem pemerintahan yang ditentukan. Meski demikian, bukan berarti Islam terpisah sama sekali dengan sistem ketatanegaraan. Di dalam Islam terdapat prinsip-prinsip universal dalam kehidupan bermasyarakat, seperti keadilan, kesederajatan, penghormatan terhadap wanita, dan hak asasi manusia, serta permusyawaratan.

Jika dibandingkan dengan kelompok kedua ada persamaan dan ada perbedaan. Persamaannya terletak pada pandangan tentang tidak adanya ajaran Islam yang mewajiban mendirikan bentuk negara tertentu, termasuk bentuk negara Islam. Hal ini karena bentuk negara yang hendak dibentuk lebih didasarkan pada konsensus masyarakat di mana mereka berada. Adapun perbedaannya, kelompok ketiga berpendapat bahwa Islam telah memberikan dasar-dasar bernegara secara garis besar, sedangkan kelompok kedua menyatakan bahwa Islam sama sekali tidak mengatur urusan kenegaraan. Semuanya diserahkan kepada hasil pemikiran manusia belaka.

${ }^{24}$ Munawir Sjadzali, Islam dan Tata Negara; Ajaran, Sejarah dan Pemikiran, 100.

25 Ibid. 
Tokoh utama kelompok ketiga, Husein Haikal berpendapat bahwa prinsip-prinsip dasar kehidupan kemasyarakatan yang diberikan oleh al-Qur'an dan Hadis tidak ada yang langsung berkaitan dengan ketatanegaraan. Adapun prinsip-prinsip dasar yang paling penting sebagai sendi kehidupan bermasyarakat adalah: Beriman kepada Tuhan yang Esa, dari prinsip dasar keimanan inilah lahir prinsip persamaan, persaudaraan, dan kebebasan.

Sedangkan tokoh utama kelompok kedua adalah Ali Abdul Raziq atau yang lebih dikenal sebagai ar-Raziq. Ia menulis buku yang sangat terkenal, al-Islâm wa Ushûl al-Hukm. Buku ini terbit di Kairo, pada tahun 1925, tepat setahun setelah kekhalifahan Turki Utsmani runtuh pada 1924.

Pandangan ar-Raziq tentang kenegaraan menyatakan bahwa mendirikan negara semata-mata merupakan kebutuhan hidup manusia yang tidak bisa hidup tanpa orang lain. Bernegara adalah dorongan alamiah manusia untuk berkumpul mengorganisasi diri untuk hidup dan mencapai tujuan bersama. Nabi Muhammad semata-mata seorang utusan Allah untuk mendakwahkan agama murni tanpa maksud mendirikan negara.

Pemikiran Ali Abdul Raziq ini selaras dengan pemikiran Muhammad Arkoun dan Fazlur Rahman. Ketiganya menyatakan bahwa politik adalah arena profan yang tidak ada sangkut pautnya dengan perkara agama. Negara Madinah tidaklah termasuk perkara sunnah amali karena itu adalah praktik yang bersifat rasional dan hasil pilihan rasional (ijtihadi). Sebab itulah, negara boleh saja mengambil bentuk modern nation-state bersistemkan demokrasi. Boleh republik, boleh kerajaan, keamiran, atau kesultanan. ${ }^{26}$

Menurutnya, Muhammad tidak memiliki kekuasaan duniawi, negara, maupun pemerintahan. Nabi tidak mendirikan kerajaan dalam arti politik atau sesuatu yang mirip dengan kerajaan. Dia

${ }^{26}$ Yasin, "Pemetaan Pemikiran Islamic State, Khilafah dan Nation State Perspektif Fiqh al-Siyasi." 
adalah nabi semata sebagaimana halnya Nabi-Nabi sebelumnya. Muhammad bukan raja, tidak pula pendiri negara dan tidak pula mengajak umat untuk mendirikan kekuasaan duniawi. ${ }^{27}$ Pemikiran ini memisahkan benar-benar antara perkara agama dengan perkara tata negara. Dengan bahasa lain, pemikiran ini menganjurkan sistem sekular dalam perkara tata negara. ${ }^{28}$

Negara Madinah yang dibentuk Muhammad, menurut Ali Abdul Raziq adalah buah kesepakatan masyarakat yang sama sekali lepas dari urusan agama. Ini seperti teori kontrak sosial yang disampaikan John Lock sebagai panctum unionis. Bahwa satu komunitas masyarakat bersepakat untuk menyerahkan sebagian kuasa atas dirinya sendiri kepada beberapa pihak yang mereka pilih untuk menyelenggarakan pemerintahan dan pengaturan atas urusan-urusan mereka. ${ }^{29}$

Persepsi Akademisi Muslim di Kota Metro terhadap Ajaran Kewajiban Mendirikan Negara Islam di Indonesia a. Kewajiban Mendirikan Negara Islam di Indonesia

Dalam upaya menulis artikel ini, penulis mewawancarai beberapa narasumber yang relevan. Yang pertama diwawancarai adalah Bambang Suhada. Ia adalah dosen Universitas Muhammadiyah Metro. Dalam jabatan struktural di kampus, ia menjabat sebagai Wakil Rektor dalam bidang sarana dan prasarana.

Penulis menanyakan bagaimana persepsinya terhadap konsep bernegara dalam Islam; apakah ada ajaran bernegara dalam Islam yang mewajibkan mendirikan Negara Islam, Bambang Suhada menyatakan bahwa ia kurang memahami konsepsi bernegara dalam Islam. Hal ini karena riwayat pendidikan Bambang Suhada dari S1 sampai S3 dijalani di luar Perguruan Tinggi Keagamaan Islam (PTKI). ${ }^{30}$

27 Munawir Sjadzali, Islam dan Tata Negara; Ajaran, Sejarah dan Pemikiran, I42-43.

28 Yasin, "Pemetaan Pemikiran Islamic State, Khilafah dan Nation State Perspektif Fiqh al-Siyasi."

29 Ibid., , 163.

30 Bambang Suhada, Wawancara, Kota Metro, 12 Agustus 2017. 
Meskipun demikian, Bambang menyatakan bahwa pada dasarnya bentuk negara-bangsa yang dianut di Indonesia yang berdasarkan Pancasila, bukan negara Islam adalah pilihan yang ideal. Hal ini mengingat Indonesia merupakan bangsa yang plural, yang berBhinneka Tunggal Ika, sehingga untuk menjaga keutuhan bangsa, maka bentuk Negara Kesatuan Republik Indonesia yang ada di Indonesia sudah merupakan bentuk yang maksimal. ${ }^{31}$

Narasumber kedua yang penulis wawancarai adalah M. Soleh Abdur Rahman. Ia adalah dosen di Fakultas Syariah IAIN Metro. Selain itu, ia juga berkiprah sebagai Ketua Majelis Ulama (MUI) Kota Metro. Ketika diwawancarai, M. Soleh Abdur Rahman menyatakan bahwa di dalam khasanah politik Islam perbedaan pendapat yang berkaitan dengan kewajiban mendirikan negara.

Pertama, kelompok yang berpendapat bahwa Islam merupakan agama yang lengkap mengandung semua ajaran termasuk ajaran ketatanegaraan Islam. Hal ini karena Islam memiliki sistem pemerintahan sendiri yang harus ditegakkan dan tidak boleh menganut sistem pemerintahan lain selain Islam seperti halnya sistem Barat. Begitu juga, mendirikan negara Islam adalah kewajiban atas dasar perintah agama. Pendirian negara Islam diperlukan untuk menjamin dijalankannya perintah agama. $^{32}$

Kedua, kelompok yang berpendapat bahwa Islam sama sekali tidak mengatur persoalan ketatanegaraan. Oleh karena itu, umat Islam dibebaskan dalam menentukan bentuk negaranya, tergantung konsensus masyarakat di mana mereka berada. Mendirikan Negara bukanlah kewajiban agama tetapi sematamata karena sunnatullah bahwa manusia tidak bisa hidup sendiri, sehingga bekerjasama secara berkelompok merupakan kodrat manusia. ${ }^{33}$

\footnotetext{
31 Ibid.

32 M. Soleh Abdur Rahman, Wawancara, Kota Metro, 20 September 2017.

33 Ibid.
} 
Ketiga, kelompok yang berpendapat bahwa Islam tidak mewajibkan pemeluknya mendirikan negara Islam, akan tetapi Islam memberikan prinsip-prinsip umum dalam bernegara seperti: keadilan, kesimbangan, kesetaraan, penghargaan hak-asasi manusia, musyawarah dan lain-lain.

Bertolak dari ketiga pendapat di atas, menurut M. Sholeh Abdur Rahman, Islam tidak mewajibkan pemeluknya untuk mendirikan negara dalam bentuk tertentu termasuk negara Islam. Mengenai bentuk negara yang hendak didirikannya, umat Islam dibebaskan untuk menentukannya sendiri berdasarkan konsensus di antara mereka. Akan tetapi negara harus menjamin diberlakukannya prinsip-prinsip Islam yang universal. ${ }^{34}$

Narasumber ketiga yang penulis wawancari adalah Iwanudin. Ia adalah dosen di Fakultas Syariah dan Ekonomi Islam IAI Maarif NU Metro. Ia juga berkiprah sebagai Ketua Pengurus Lembaga Pengembangan Sumber Daya Manusia (Lakpesdam) NU Cabang Kota Metro.

Iwanudin berpendapat bahwa tidak ada kewajiban mendirikan negara Islam di Indonesia. Menurutnya, tokoh-tokoh Islam di Indonesia yang menyepakati bentuk negara Indonesia sebagai negara-bangsa bukan negara Islam telah melalui kajian dan perdebatan yang panjang hingga akhirnya diperoleh konsensus bersama. Hal ini sudah merupakan jalan tengah yang ideal di tengah realita keanekaragaman Indonesia, yang berbeda dalam hal ras, suku, agama, dan golongan. ${ }^{35}$

Negara-bangsa juga merupakan bentuk negara pilihan ormas Islam terbesar Indonesia yaitu Nahdlatul Ulama (NU). Dalam salah satu muktamarnya, NU menyatakan bahwa Hindia Belanda, yang saat itu sedang dalam jajahan Belanda adalah Dâr as-Salâm, bukan Dâr al-Harb ataupun Daâr al-Islâm.36

\footnotetext{
34 M. Soleh Abdur Rahman, Wawancara, Kota Metro, 20 September 2017.

35 Iwanudin, Wawancara, Kota Metro, 29 September 2017.

36 Ibid.
} 
Narasumber keempat yang penulis wawancarai adalah $\mathrm{H}$. Ach. Chairy, M.Pd. Ia adalah Rektor Institut Agama Islam (IAI) Agus Salim Metro. Chairy menyatakan hal yang sama, bahwa negara-bangsa Indonesia adalah bentuk yang sudah final. Hanya saja, ada banyak gerakan yang muncul akhir-akhir ini yang ingin mendirikan negara Islam di Indonesia, baik dalam bentuk kekhilafahan maupun bentuk lain, sebagaimana yang dilakukan oleh Hizbut Tahrir Indonesia (HTI), Negara Islam Indonesia (NII) dan lain sebagainya. Chairy menegaskan bahwa gerakan melawan negara harus ditindak. ${ }^{37}$

\section{b. Kewajiban Menjalankan Syariat Islam di Indonesia}

Dalam hal pemberlakuan syariat Islam di Indonesia dalam wadah negara-bangsa yang berdasarkan Pancasila, Bambang Suhada berpendapat bahwa hal demikian tidak dapat dilakukan. Hal ini merupakan konsekuensi dari bentuk negara-bangsa yang dipilih. Umat Islam harus mengedepankan toleransi terhadap warga negara yang beragama lain. Sebaliknya, umat agama lain harus menjunjung toleransi terhadap warga negara yang beragama Islam. Dalam kondisi seperti ini, jika ada pemaksaan pemberlakukan syariat Islam di Indonesia, hal ini berpotensi memecah belah persatuan bangsa. ${ }^{38}$

Sementara itu, M. Sholeh Abdur Rahman berpendapat bahwa pada dasarnya syariat Islam di Indonesia sudah diberlakukan dalam pengertian subtansinya, nilai-nilainya. Oleh karenanya, tidak relevan lagi memperjuangkan pemberlakukan syariat Islam. Di dalam Islam, pencurian, pembunuhan, perzinahan, dan kecurangan merupakan perbuatan yang dilarang dan dikenai hukuman. Begitu juga undang-undang yang berlaku di Indonesia juga melarang dan menghukum terhadap pelaku perbuatan kriminal tersebut. ${ }^{39}$

\footnotetext{
${ }^{37}$ Ach. Chairy, Wawancara, Kota Metro, 17 Oktober 2017.

${ }^{38}$ Bambang Suhada, Wawancara, Kota Metro, 12 Agustus 2017.

39 M. Soleh Abdur Rahman, Wawancara, Kota Metro, 20 September 2017.
} 
Di tempat terpisah, Iwanudin turut berpendapat bahwa tidak wajib memberlakukan syariat Islam di Indonesia. Hukum yang berlaku di Indonesia walaupun tidak berlabel Islam, pada hakikatnya sudah Islami. Begitu juga halnya ketaatan kepada agama merupakan urusan privat masing-masing pemeluk agama yang sepenuhnya tergantung pada keimanan dan ketakwaan masing-masing. Negara tidak perlu campur tangan dalam mengawasi ibadah warga negaranya. 40

\section{c. Pemberlakuan Perda Syariah di Indonesia}

Menurut Bambang Suhada, tuntutan pemberlakuan perda syariah di beberapa daerah di Indonesia merupakan dinamika kehidupan berbangsa dan bernegara di tiap-tiap daerah yang gejalanya tidak sama. Ada daerah yang menerapkan perda syariah dan ada yang tidak. Kondisi demikian pada dasarnya tergantung pada kondisi sosial budaya dan politik lokal masing-masing. Hal semacam ini masih dapat dipahami. Menurutnya hal ini belum mengancam kehidupan yang harmoni di tengah pluralitas bangsa. ${ }^{41}$

Senada dengan pendapat Bambang Suhada, M. Soleh Abdur Rahman menyatakan bahwa pemberlakuan perda syariah dapat dipahami sebagai upaya menjaga kemaslahatan umat; agar umat lebih taat dalam menjalankan agamanya; agar umat terhindar dari perbuatan maksiat. Bagi Soleh, kehadiran perda syariah tidak mengancam keberlangsungan kehidupan berbangsa dan bernegara. ${ }^{42}$

Bertolak belakang dengan kedua pendapat di atas, Iwanudin menyatakan bahwa perda syariah tidak diperlukan. Seharusnya perda syariah bisa dianulir. Hal ini merupakan konsekuensi dari pilihan atas bentuk negara-bangsa Indonesia yang bukan negara agama tertentu. Selain itu, adanya perda syariat akan

\footnotetext{
40 Iwanudin, Wawancara, Kota Metro, 29 September 2017.

${ }^{41}$ Bambang Suhada, Wawancara, Kota Metro, 5 September 2017.

42 M. Soleh Abdur Rahman, Wawancara, Kota Metro, 20 September 2017.
} 
menimbulkan ketidakadilan apabila hanya agama tertentu di sebuah daerah yang memiliki perda yang mengatur peribadatan. ${ }^{43}$

Iwanudin menambahkan bahwa ketaatan menjalankan agama adalah urusan pribadi pemeluk agama masing-masing. Kesalehan beragama adalah urusan seorang individu dengan tuhannya. Tidak diperlukan campur tangan negara untuk mengatur hubungan manusia dengan tuhannya. Sebab itulah perda syariah tidak diperlukan. ${ }^{44}$

Di antara dua kutub pendapat yang berseberangan di atas, Chairy menyatakan bahwa pada dasarnya perda syariah merupakan suatu hal yang dilematis di Indonesia. Di satu sisi pilihan negara-bangsa bukan negara agama mengharuskan peraturan perundangan berlaku bagi semua warga negara tanpa kecuali.

Meskipun demikian, Chairy berpendapat bahwa kemunculan perda syariah di beberapa daerah juga dapat dinilai sebagai akomodasi terhadap aspirasi warga negara yang menghendaki adanya perda syariah. Meski demikian, Chairy menggarisbawahi bahwa sejauh ini kemunculan perda syariah yang terjadi di beberapa daerah masih belum membahayakan NKRI. ${ }^{45}$

\section{Persepsi Akademisi Kota Metro terhadap Relasi Agama dan Negara}

\section{a. Negara-Bangsa Indonesia sudah Final dan Ideal}

Akademisi muslim di Kota Metro berpandangan bahwa pilihan bentuk negara-bangsa sebagaimana dianut Indonesia adalah bentuk yang ideal. NKRI berdasarkan Pancasila dan Undang-Undang Dasar 1945, bukan negara agama atau negara Islam. Hal ini mempertimbangkan realitas kebhinekaan warganegaranya yang terdiri dari ratusan suku, ras, dan agama yang berbeda-beda.

\footnotetext{
43 Iwanudin, Wawancara, Kota Metro, 29 September 2017.

44 Ibid.

45 Ach. Chairy, Wawancara, Kota Metro, 17 Oktober 2017.
} 
Meskipun para akademisi menggunakan ungkapan yang berbeda dan alasan yang beragam, pada dasarnya dapat ditarik beberapa garis pokok argumentasi mereka bahwa:

a. Ajaran Islam tidak mengandung nash yang mewajibkan umatnya untuk mendirikan negara Islam dan atau negara dengan sistem khilafah. Umat Islam dibebaskan untuk mendirikan negara dengan bentuk apapun yang mereka sepakati. Ajaran Islam tentang kenegaraan hanya bersifat nilai-nilai seperti: keadilan, keseimbangan, ketuhanan, musyawarah, penghargaan terhadap hak asasi manusia, dan lain-lain. Nilai-nilai inilah yang harus menjadi landasan dalam kehidupan berbangsa dan bernegara. Persepsi demikian disampaikan oleh M. Soleh Abdur Rahman dan Iwanudin.

b. Pendapat lain menyatakan bahwa pilihan negara-bangsa sebagai bentuk negara Indonesia merupakan jalan tengah yang menjadi konsensus di antara para pendiri bangsa. Hal ini dilakukan untuk menghindari ancaman perpecahan atau disintegrasi bangsa. Pendapat ini disampaikan oleh Bambang Syuhada dan Ach. Chairy.

\section{b. Hukum Publik Islam Tidak Dapat Diberlakukan}

Akademisi muslim Kota Metro tidak setuju dengan pemberlakuan syariat Islam sebagai hukum publik di Indonesia. Syariat Islam dalam ruang publik yang dimaksud sebagaimana tuntutan beberapa kelompok yang marak akhir-akhir ini yaitu: hukum potong tangan bagi pencuri, hukuman rajam bagi pezina, dan hukuman qishash bagi pelaku pembunuhan. Adapun alasan yang dikemukakan adalah sebagai berikut:

a. Pemberlakuan syariat Islam dalam perkara hukum publik tersebut tidak relevan menjadi tuntutan sebagian kelompok Islam di Indonesia, karena pada dasarnya hal tersebut sudah diakomodir dalam sistem hukum Indonesia dalam bentuk akomodasi nilai-nilai dan subtansinya. 
b. Absennya pemberlakuan syariat Islam di Indonesia terutama dalam hukum publik sebagai konsekuensi pilihan bentuk negara Pancasila bukan negara agama, sehingga apabila hal tersebut dilakukan, berpotensi akan memecah belah bangsa.

\section{c. Antara Menerima dan Menolak Perda Syariah}

Dalam hal pemberlakukan perda syariah di Indonesia, ada akademisi yang berpendapat bisa menerima dan ada yang berpendapat tidak dapat menerima. Adapun alasan akademisi yang dapat menerima perda syariah adalah:

a. Pemberlakukan perda syariat hanya terjadi di beberapa daerah pada dasarnya merupakan cerminan dinamika sosial budaya dan politik lokal di daerah sebagai upaya menangkap aspirasi masyarakat setempat, hal tersebut dapat dipahami dan tidak membahayakan integrasi bangsa.

b. Pemberlakuan syariat Islam dapat dipahami dan diterima sepanjang tujuannya untuk kemaslahatan umat.

Sedangkan akademisi muslim yang tidak dapat menerima perda syariah memiliki argumentasi bahwa:

a. Perda syariah adalah bentuk ketidakadilan terhadap warganegara yang beragama selain Islam, sehingga dapat menimbulkan kecemburuan, dan hal ini melanggar Pancasila dan UUD 1945.

b. Beragama merupakan urusan antara individu dan tuhannya yang merupakan urusan privat, sehingga tidak perlu dilegalkan melalui perda syariah.

\section{Penutup}

Akademisi muslim di kota Metro menyatakan bahwa negarabangsa Indonesia adalah bentuk final dan ideal dalam konteks Indonesia. Hal ini karena mempertimbangkan berbagai faktor sejarah, sosial, budaya, fakta Indonesia yang berbhineka. Argumentasi yang disampaikan ada dua: (i) Islam tidak mengatur secara rigid terkait kewajiban mendirikan negara dalam bentuk 
tertentu, dan (ii) bentuk negara-bangsa memungkinkan terjadinya persatuan bangsa Indonesia.

Lebih lanjut, akademisi muslim di kota Metro kompak menyatakan bahwa penerapan hukum Islam dalam ranah publik di Indonesia tidak bisa diberlakukan karena dua alasan: Pertama, secara prinsipil nilai-nilai hukum publik Islam sudah diterapkan dalam sistem hukum nasional. Kedua, absennya hukum Islam dalam ranah publik adalah konsekuensi bentuk negara-bangsa Indonesia.

Meski demikian, di kalangan akademisi ada sikap mendua terhadap perda syariat. Sebagian akademisi menerima dengan dua argumen: (i) perda syariah adalah wujud aspirasi yang bersifat khusus dan lokal dan (ii) sepanjang tujuannya maslahat. Sedangkan akademisi yang menolak perda syariah beralasan: (i) perda syariah mewujudkan ketidakadilan bagi warganegara nonmuslim, (ii) agama adalah ranah privat.

\section{Daftar Pustaka}

Ahmadi, Abu. Ilmu Sosial Dasar. Jakarta: Rineka Cipta, 1997.

Hamidy, Abu Dzarrin al-. "Landscape Pemikiran Abu al-A'la alMawdudi (1903-1979) tentang Konsep Negara Islam." alDaulah: Jurnal Hukum dan Perundangan Islam 1, No. 2 (1 Oktober 2011).

Hatta, Muhammad. "Tanggungjawab Moral Kaum Intelegensia." In Cendikiawan dan Politik. Jakarta: LP3ES, 1984.

Ilmi, Miftahul. Persepsi Ulama NU tentang Sistem Khilafah. Semarang: Skripsi Fakultas Syari'ah IAIN Walisongo, 2008.

Jailani, Imam Amrusi. "Tarik Ulur Islam dan Dasar Negara." alDaulah: Jurnal Hukum dan Perundangan Islam 2, No. 1 (1 April 2012).

Ma'shum. "Islam dan Pencarian Identitas Politik (Ambiguitas Sistem Khilafah dalam Institusi Politik Islam)." Asy-Syir'ah: Jurnal Ilmu Syari'ah dan Hukum 47, No. 2 (1 Juli 2013). 
http://asy-syirah.uinsuka.com/index.php/AS/article/view/71.

Muhammad, Ali Abdul Mu'ti. Filsafat Politik antara Islam dan Barat. Diterjemahkan oleh Rosihan Anwar. Bandung: Pustaka Setia, 2010.

Muhammadin. "Gerakan Dakwah Hizbut Tahrir Indonesia." Jurnal Ilmu Agama 17, no. 1 (13 Juli 2016).

Rafiuddin, Mohamad. "Mengenal Hizbut Tahrir (Studi Analisis Ideologi Hizbut Tahrir vis a vis NU)." ISLAMUNA: Jurnal Studi Islam 2, No. 1 (5 Juni 2015).

Saoki, Saoki. "Islam dan Negara Menurut M. Natsir dan Abdurrahman Wahid." al-Daulah: Jurnal Hukum dan Perundangan Islam 4, No. 02 (2014).

Shihab, M. Quraish. "Membumikan" Al-Quran: Fungsi dan Peran Wahyu dalam Kehidupan Masyarakat. Bandung: Mizan Pustaka, 2007.

Sjadzali, Munawir. Islam dan Tata Negara; Ajaran, Sejarah dan Pemikiran. Jakarta: UI Press, 1993.

Yasin, Achmad. "Pemetaan Pemikiran Islamic State, Khilafah dan Nation State Perspektif Fiqh al-Siyasi." al-Daulah: Jurnal Hukum dan Perundangan Islam 2, No. 2 (1 Oktober 2012).

Zionis, Rijal Mumazziq. "Relasi Agama dan Negara Perspektif KH. A. Wahid Hasyim dan Relevansinya dengan Kondisi Sekarang." al-Daulah: Jurnal Hukum dan Perundangan Islam 5, No. 2 (1 Oktober 2015).

\section{Informan}

Ach. Chairy, Oktober 2017.

Bambang Suhada, Agustus 2017.

Iwanudin, 29 September 2017.

M. Soleh Abdur Rahman, 20 September 2017. 